\title{
The Relationship between Economic Freedom, State Growth and Foreign Direct Investment in US States
}

\author{
Dennis Pearson ${ }^{1}$, Dong Nyonna ${ }^{1} \&$ Kil-Joong Kim ${ }^{1}$ \\ ${ }^{1}$ School of Business, Austin Peay State University, Clarksville, TN 37044, USA \\ Correspondence: Dennis Pearson, College of Business, Austin Peay State University, Clarksville, TN 37044, \\ USA. Tel: 931-221-7851. E-mail: pearsond@apsu.edu
}

Received: July 23, 2012

Accepted: August 17, $2012 \quad$ Online Published: September 7, 2012

doi:10.5539/ijef.v4n10p140

URL: http://dx.doi.org/10.5539/ijef.v4n10p140

\begin{abstract}
"There is one and only one social responsibility of business - to use its resources and engage in activities designed to improve its profits so long as it stays within the rules of the game, which is to say, engages in open and free competition, without deception and fraud."
\end{abstract}

Milton Friedman

Researchers have identified economic freedom, growth rate of the economy, per capita income, unemployment rate, etc as determinants of foreign direct investment (FDI) inflows into the United States as a country. Whether or not these economic variables also determine FDI at the states' level is often excluded from the literature.

This paper attempts to fill that gap by using a panel data from 1984 through 2007 for all 50 states. We employ the random effects regression model and find that both economic freedom and growth rate in each state are significant positive determinants of FDI inflows. This result is consistent with that of Ray (1989) who shows that high economic growth in the U. S. leads to more FDI inflows. Bengoa and Sanchez-Robles (2003), and Kapuria-Foreman (2007) document similar results for Latin American countries.

In addition, we show that both per capita income and unemployment rate exhibit significant negative relations with FDI. These results are consistent with that of Edwards (1992) and Jaspersen, Aylward, and Knox (2000), but inconsistent with that of Tsai (1994) and Lipsey (1999). We attribute the negative relation between FDI and per capita income to the fact that states with higher per capita income tend to discourage FDI inflows since higher per capita income translates into higher wages. The observed inverse relation between FDI and unemployment rate is due to the fact that states with high unemployment rates are more prone to crime, and therefore deters risk-averse foreign investors from assuming a lasting interest in those states.

Keywords: economic freedom, Foreign Direct Investment, growth

JEL Classification: C33, H7, H30, F21

\section{Introduction}

The Economics and Statistics Administration of the U.S. Department of Commerce documents that foreign direct investment (FDI) (Note 1) into the U.S. over the past decade has supported more than 5 million U.S. jobs and that on average, those jobs pay 30 percent more than other jobs (Note 2). These findings point the way toward policies that could expand the number of foreign partners investing in the United States and, in so doing, create more high-paying U.S. jobs.

Policymakers at the state and local government levels obviously expect FDI inflows to help improve income and employment aspects of their residents. Consequently, all 50 states in the U.S. compete aggressively for FDI (Graham and Krugman 1995; Casey 1998; Head et al. 1999; Torau and Goss 2004). More evidence of aggressive competition among U. S. states for FDI inflows is found in the Nov. $24^{\text {th }}, 1993$ edition of the Wall Street Journal, where the state of Alabama is reported to have promised Mercedes-Benz well over $\$ 300$ million if it located its first U.S auto manufacturing plant in that state.

Considering the crucial role FDI plays in the economic development of a nation, tremendous amount of research on its determinants exists. Many economists identify economic freedom, growth rate of the economy, per capita 
income, unemployment rate, etc as determinants of FDI. Whether or not these determinants of FDI at the national level also impact FDI inflows at the state level is often excluded from the literature.

This paper attempts to fill that gap by using a panel data from 1984 through 2007 for all 50 states. We employ the random effects regression model and find that both economic freedom and growth rate in each state are significantly positively related to FDI. In addition, we show that both unemployment rate and per capita income are negatively related to FDI inflows into the states. We attribute this negative relation between FDI inflows and unemployment to the fact that high unemployment may lead to crime, and so discourages risk-averse foreign investor. Since high per capita income translates into high wages, we attribute the inverse relation between per capita income and inflows of FDI to entrepreneurs trying to avoid states with high wages.

Our paper contributes to the literature in the following manner. Since the 50 states in the U. S. are not homogeneous in terms of policy and regulations, our study seeks to find out whether the determinants of FDI at the national level also determine FDI at the state level. We find that both economic freedom and growth rate of the economy are direct contributory factors to FDI inflows. On the other hand, both the state's unemployment rate and per capita income negatively impact FDI inflows into that state.

From a policy perspective, state and local government authorities should promote a business environment consistent with economic freedom that fosters economic growth in order to attract inflows of FDI. In addition, since high unemployment discourages foreign entrepreneurs from investing, state governments should institute measures aimed at mitigating the unemployment menace.

The rest of the paper is organized as follows. Section 2 discusses the economic variables used in the study and testable hypotheses. Section 3 reports the data and methodology. The results are reported in section 4, and section 5 concludes the paper.

\section{Economic Variables and Hypotheses}

Researchers in foreign direct investment argue that inflow of FDI plays an important role in the socioeconomic and technological developments of the host nation. In particular, FDI inflows provide capital for domestic investment. In addition, the host country benefits from tax revenues through increased economic activities resulting from FDI capital inflow. Considering the significant role FDI plays in the economic development of developing countries (in particular) a number of studies have evolved on the determinants of FDI. Most of these studies identify the degree of economic freedom, the growth rate of the economy, the per capita income (or the size of the market), the unemployment rate for the host economy, etc, as determinants of FDI. Next, we discuss each of these variables and their relationships with inflows of FDI.

\subsection{Economic Freedom}

"Modern economic growth is mainly about brain power and sound policy. Investment capital and entrepreneurial talent will flow toward economies with low taxes, secure property rights, sound money and sensible regulatory policies. In contrast, when these factors are absent, people will find more attractive environments somewhere. Nations prosper when they provide a climate that encourages their citizens, often in cooperation with foreigners, to discover and adopt better ways of doing things, "Gwartney and Lawson (2001).

The above quote implies that inflows of FDI do not necessarily flow to where it is needed the most; it flows to economies with the most conducive business environments. The degree of economic freedom, which measures the conduciveness of a business environment, is defined by Caetano and Caleiro (2009) as "the degree to which a market economy is in place, where the central components are voluntary exchange, free competition, and protection of persons and property." Two indexes measure the degree of economic freedom. One is the Fraser's Institute Economic Freedom World (EFW) Index and the other is the Heritage Foundation Economic Freedom Index of the World. Our analysis utilizes the Fraser's Institute degree of economic freedom index. The index quantifies forty-two data points in five broad areas (size of government; legal structure and security of property rights; access to sound money; freedom to trade internationally; and regulation of credit, labor, and business) into a composite score on a scale of 0 to 10 , with 10 representing the highest degree of economic freedom (see Gwartney, Lawson, and Hall, 2011).

Kapuria-Foreman (2007) examines the determinants of FDI using data from 1990-1998 for a number of developing countries and document that FDI varies positively with higher levels of certain components of the economic freedom index. In another study of 18countries, Quazi (2007) use the economic freedom index published by the Heritage Foundation as a proxy for "domestic investment climate" and show that economic freedom is a significant positive determinant of FDI. In a related study, Bengoa and Sanchez-Robles (2003) 
analyze a sample of 18 Latin American countries from 1970-1999 and report that economic freedom is a positive determinant of FDI inflows.

Utilizing a pooled time-series and cross sectional data from 1979-85, Ray (1989) show that an increase in nontariff trade barrier protection, which is a component of economic freedom, in the United States leads to an increase in foreign direct investment in U. S. manufacturing activities. Another component of economic freedom that is shown to have a positive effect on FDI inflows is the tax rate of the host nation. Both Cassou (1997) and Billington (1999) show that low corporate tax rates in host countries attract FDI inflows. In addition, Kemsley (1998) provides evidence that tax serves as an incentive for U.S. multinational corporations to export to foreign markets rather than undertaking green field investment. The degree of openness to international trade, measured by the ratio of the sum of exports and imports to GDP, is another component of economic freedom. This component is shown to exhibit a strong positive relation with FDI inflows (Edwards, 1992).

In view of these documentations on the relationship between economic freedom and inflows of FDI in developing countries, we have no reason to believe the relationship would be different in the $50 \mathrm{U}$. S. states. Hence our hypothesis on the relationship between FDI and economic freedom in the 50 U. S. states follows.

Hypothesis 1: States with higher degree of economic freedom (as provided by the Fraser Institute) should have higher inflow of FDI.

\subsection{Growth Rate of the Economy}

Advanced by Lim (1983), the growth hypothesis postulates that a rapidly growing economy has better opportunities (from the perspective of the foreign investor) for profit maximization than those that are stagnant. In support of this hypothesis, Tsai (1994) acknowledged that most studies on the determinants of FDI consider economic growth rate of the recipient country as a crucial factor attracting inflows of FDI. According to Hansen and Rand (2006), the consensus seems to be that of a positive relationship between FDI inflows and economic growth in host countries provided the receiving countries have achieved a minimum level of educational, technological, and/or infrastructural development.

Using a 40-year period of annual data, Asheghian (2004) analyzes the role of FDI on U.S. economic growth and document that FDI has a significant positive impact on the U.S. economic growth. However, Chowdhury and Mavrotas (2006) test the direction of causality between FDI and economic growth for three major FDI recipient countries and report mixed results. They fail to confirm the conventional view that the direction of causality runs from FDI to economic growth for one host country, and document a bi-directional relationship between FDI and growth rate for the other two recipient countries. In another study, Ray (1989) show that high economic growth in the United States tends to influence the decision by foreign firms to invest in the United States.

In summary, we consider growth as a crucial determinant of FDI. Risk-averse foreign investors will be attracted to a high-growth economy where the possibility exists for an expanding domestic market. As a result, we argue that states experiencing rapid growth will be more attractive to foreign investors than states with declining growth. Consequently, the second hypothesis becomes:

Hypothesis 2: States with high economic growth should experience more FDI inflow than states with low economic growth.

\subsection{Per Capita Income}

Many studies have analyzed the relationship between inflows of FDI to the host nation and per capita income and found mixed results. Using a pooled aggregate data for 62 countries over the period 1975-1978 and for 51 countries from 1983-1986, Tsai (1994) and Lipsey (1999) document a positive relationship between FDI and per capita income. On the contrary, Edwards (1992) and Jaspersen, Aylward, and Knox (2000) find a significant negative relation. In our view, high per capita income, which is a consequence of high wages, tends to discourage FDI inflows. The reason is that rational entrepreneurs realizing the benefits of lower labor cost will most likely locate their businesses in economies where wages are lower (ceteris paribus). Furthermore, Leibrecht and Scharler (2009) study the importance of labor market conditions in Central and Eastern European countries and find that countries with lower labor costs have high FDI inflows. Even though these studies were conducted on developing nations, we believe to some extent, the U.S. states behave in a similar fashion. Therefore the hypothesis on per capita income and FDI follows.

Hypothesis 3: States with lower per capita income will attract more FDI than states with higher per capita income. 


\subsection{Rate of Unemployment}

The relationship between unemployment rate and FDI inflows is mixed. Billington (1999) notes that high unemployment, which is a proxy for the availability of labor in the host country encourages FDI inflows. On the contrary, using a simple partial equilibrium model of foreign direct investment in the U. S., Ray (1989) provides evidence regarding the degree to which FDI might lower the unemployment rate. We believe high unemployment rate should lead to socio-economic problems like high crime rate and high rate of school dropout (ceteris paribus). The consequence of high rate school dropout is scarcity of skilled labor force in the long-run. As a result no rational enterprise will want to have lasting interest in such an environment. Therefore, our hypothesis on the relationship between unemployment rate and FDI inflows is the following.

Hypothesis 4: States with higher unemployment rates attract less FDI inflows than states with lower unemployment rates.

\section{Data and Methodology}

\subsection{Sources of Data}

We utilize a panel data of 1,150 observations from 1984 through 2007. All data points are reported in two versions: All-Government Index, and Sub-national Index. We obtain inward foreign direct investment (FDI) data for each of the 50 U.S. states from the Bureau of Economic Analysis (BEA). Data on economic freedom (ER) for each 50 U.S. states is obtained from the Frasier Institute (Note 3). Next, data on growth rate (Growth) for each state is obtained from the BEA, while data on states' unemployment rates (Unemp) is obtained from the Bureau of Labor Statistics (BLS). Finally, data on per capita income (Pcap) by state is obtained from the BEA.

\subsection{Methodology}

Consistent with the literature on panel data estimation, we employ the random effects model to estimate the following regression model.

$$
F D I_{i t}=\beta_{o}+\beta_{1} E F_{i t}+\beta_{2} \text { Growth }_{i t}+\beta_{3} \text { Pcap }_{i t}+\beta_{4} U_{n e m p}+\varepsilon_{i t},
$$

where:

$F D I_{i t}$ is the inward foreign direct investment for state $i$ at time $t$. It is computed as

$\operatorname{Ln}\left(F D I_{t} / F D I_{t-1}\right) * 100$.

$E F_{i t}$ is the economic freedom for state $i$ at time $t$. This variable is hypothesized to have a direct relation with FDI for each state.

Growth $_{i t}$ represents the growth rate of state $i$ at time $t$. It is computed as $\operatorname{Ln}\left(G S P_{t} / G S P_{t-1}\right) * 100$, where $G S P_{t}$ is the Gross State Product at time $t$. Like the economic freedom variable, growth rate in each state is expected to have a positive relation with FDI.

Pcap $_{i t}$ is the per capita income for state $i$ at time $t$. Per capita income on the other hand is expected to have a negative relation with FDI.

Unemp $_{i t}$ depicts the unemployment rate for state $i$ at time $t$. A state's unemployment rate is hypothesized to have a negative relation with FDI.

$\varepsilon_{i t}$ is the error term

\section{Empirical Results}

Our regression results using the all-government index version of the data is depicted on the table below: 
Table 1. Regression of FDI on ER, Growth Rate, Pcap, and Unemp:

Model: $F D I_{i t}=\beta_{o}+\beta_{1} E F_{i t}+\beta_{2}$ Growth $_{i t}+\beta_{3}$ Pcap $_{i t}+\beta_{4}$ Unemp $_{i t}+\varepsilon_{i t}$,

\begin{tabular}{llll}
\hline Variable & Coefficient & Standard Error & t-Statistic \\
\hline EF & 6.2032 & 1.5099 & $4.1083^{* * *}$ \\
Growth & 0.2727 & 0.1334 & $2.0434^{* *}$ \\
Pcap & -0.0004 & 0.0001 & $-7.9028^{* * *}$ \\
Unemp & -2.0474 & 0.3725 & $-5.4966^{* * *}$ \\
Total (Pooled) Observations & 1,150 & & \\
R-Squared & $12.15 \%$ & & \\
Adj R-Squared & $7.9 \%$ & & \\
\hline
\end{tabular}

*** Significant at $1 \%$ level, ${ }^{* * \text { Significant at } 5 \% \text { level }}$

All the variables have their expected signs and are highly significant at the $1 \%$ level except for the Growth rate variable, which is significant at the $5 \%$ level. The coefficient on the economic freedom variable (EF) is positive and highly significant at the one percent level, supporting hypothesis 1 , which states that a high degree of economic freedom in a particular state will lead to an increase in FDI inflows into that state. This is consistent with Gwartney and Lawson (2001) who purport that investment capital and entrepreneurial talent will flow toward economies with low taxes, secure property rights, sound money, and sensible regulatory policies. Similarly, the coefficient on the growth variable (Growth) is positive and significant. This supports our second hypothesis, which implies higher growth rates attract more FDI inflows. These results are consistent with that of Ray (1989) who show that high economic growth in the U. S. leads to more FDI inflows. Bengoa and Sanchez-Robles (2003), and Kapuria-Foreman (2007) document similar results for Latin American countries.

The coefficients on both per capita income (Pcap) and unemployment (Unemp) variables are both negative and highly significant indicating the negative relationship between these variables and FDI inflows. Higher per capita income, which translates into higher wages, discourages FDI inflows. Similarly, high unemployment with its concomitant social vices tends to scare away risk-averse foreign entrepreneurs. These results are consistent with that of Jaspersen, Aylward, and Knox (2000); and Edwards (1992), but inconsistent with that of Tsai (1994) and Lipsey (1999).

We attribute the negative relation between FDI and per capita income to the fact that states with higher per capita income tend to discourage FDI inflows since higher per capita income translates into higher wages. The observed inverse relation between FDI and unemployment rate is due to the fact that states with high unemployment rates are more prone to crime, and therefore deters risk-averse foreign investors from assuming a lasting interest in those states.

For robustness, we estimate the same model above using the sub-national index version of the data. However, we do not report the results since they are very similar to those of the all-government index.

\section{Conclusion}

Using a panel data from 1984 through 2007, the study looks at the relationship between foreign direct investment (FDI) and a number of economic variables hypothesized to explain FDI in each of the $50 \mathrm{U}$. S. states. We find that both the degree of economic freedom (for each state) as measured by the Fraser's Institute Economic Freedom World Index and the state's growth rate exhibit a direct relationship with FDI. This is expected since all things being equal a "frictionless" economic environment should attract more business investment. This finding is consistent with Edwards (1992) and Ray (1989). Second, we document that, high levels of both unemployment rate and per capita income in a state lead to low levels of FDI in that state. We attribute this result to the fact that high per capita income translates into high wages, which tends to discourage the inflow of FDI. In addition, the negative relation between unemployment rate and FDI inflows can be attributed to the fact that high unemployment rate can lead to a high crime rate, which discourages risk-averse foreign entrepreneurs from taking a lasting interest in that economy.

From a policy perspective, state and local government authorities should promote a business environment consistent with economic freedom that fosters economic growth in order to attract inflows of FDI. Pro-FDI policies should be implemented at the state level. In addition, since high unemployment discourages foreign 
entrepreneurs from investing, state governments should institute measures aimed at mitigating the unemployment menace.

\section{References}

Asheghian, Parviz. (2004). Determinants of Economic Growth in the United States: The Role of Foreign Direct Investment. The International Trade Journal, 18(1), 63-83. http://dx.doi.org/10.1080/08853900490277350

Bengoa, Marta, \& Sanchez-Robles. (2003). Foreign Direct Investment, Economic Freedom and Growth: New Evidence from Latin America. European Journal of Political Economy, 19, 529-545. http://dx.doi.org/10.1016/S0176-2680(03)00011-9

Billington, Nicholas. (1999). The Location of Foreign Direct Investment: An Empirical Analysis. Applied Economics, 31(1), 65-76. http://dx.doi.org/10.1080/000368499324561

Caetano, Jose, \& Caleiro, Antonio. (2009). Economic Freedom and Foreign Direct Investment: How Different are the MENA Countries from the EU. iBusiness, 1, 65-74. http://dx.doi.org/10.4236/ib.2009.12010

Cassou, Steven, P. (1997). The Link Between Tax Rates and Foreign Direct Investment. Applied Economics, 29(10), 1295-1301. http://dx.doi.org/10.1080/00036849700000019

Chowdhury, Abdur, \& Mavrotas, George. (2006). FDI and Growth: What Causes What? The World Economy, 29(1), 9-19. http://dx.doi.org/10.1111/j.1467-9701.2006.00755.x

Edwards, Sebastian. (1992). Capital Flows, Foreign Direct Investment, and Debt-Equity Swaps in Developing Countries. NBER Working Paper No. 3497.

Goldsmith, Arthur. (1995). Democracy, Property Rights and Economic Growth. The Journal of Development Studies, 32(2), 157-174. http://dx.doi.org/10.1080/00220389508422409

Gwartney, James, Lawson, Robert, \& Hall, Joshua. (2011). Economic Freedom of the World. Fraser Institute.

Hansen, Henrik, \& Rand, John. (2006). On the Causal Links Between FDI and Growth in Developing Countries. The World 29(1), 21-41. Wiley Blackwell. http://dx.doi.org/10.1111\%2Fj.1467-9701.2006.00756.x

Jaspersen, S., Aylward, A,, \& Knox, A. (2000). The Effects of Risks on Private Investment: Africa Compared with Other Developing Areas. In P. Collier and C. Pattillo (Eds.), Investments and Risks in Africa, pp 71-95. New York. St. Martin's Press.

Kapuria-Foreman, Vibha. (2007). Economic Freedom and Foreign Direct Investment in Developing Countries. The Journal of Developing Areas, 41(1), 143-145. http://dx.doi.org/10.1353/jda.2008.0024

Kemsley, Deen. (1998). The Effect of Taxes on Production Location. Journal of Accounting Research, 36(2), 321-341. http://dx.doi.org/10.2307/2491480

Klein, Michael, \& Rosengren, Eric. (1994). The Real Exchange Rate and Foreign Direct Investment in the United States: Relative Wealth vs. Relative Wage Effects. Journal of International Economics, 36(3-4), 373-389.

Leibrecht, Markus, \& Scharler, Johann. (2009). How Important is Employment Protection Legislation for Foreign Direct Investment Flows in Central and Eastern European Countries? http://dx.doi.org/10.1111/j.1468-0351.2009.00353.x

Lim, David. (1983). Fiscal Incentive and Direct Foreign Investment in Less Developed Countries. The journal of Development Studies, 19(2), 207-212.

Lipsey, Robert. (1999). The Location and Characteristics of U. S. Affiliates in Asia. NBER Working Paper No. 6876.

Quazi, M. Rahim. (2007). Foreign Direct Investment in Latin America: A Panel Regression Study. The International Journal of Business and Finance Research, 1(1), 59-67.

Ray, Edward John. (1989). The Determinants of Foreign Direct Investment in the United States, 1979-85, in Robert C. Feenstra, ed., Trade Policies for International Competitiveness, p.53-84. University of Chicago Press.

Tsai, Pan-Long. (1994). Determinants of Foreign Direct Investments and its Impact on Economic Growth. Journal of Economic Development, 19, p.137-163. 


\section{Notes}

Note 1. The International Monetary Fund (IFM) defines Foreign Direct Investment (FDI) as "an investment that is made to acquire a lasting interest in an enterprise operating in an economy other than that of the investor with the purpose being to have an effective voice in the management of the enterprise."

Note 2. www.esa.doc.gov/Reports/foreign-direct-investment-united-states

Note 3. This Economic Freedom of the World Index for the Fraser Institute is a composite score based on quantitative data. 